\title{
Assessment of factors influencing the development of drying shrinkage in concretes produced in Cuba
}

\author{
Evaluación de los factores que influyen en el desarrollo de la retracción por secado en los \\ hormigones producidos en Cuba
}

Fecha de envío: 29 de octubre 2018

Fecha de aceptación: 9 de agosto 2019

\section{Rafael Ramírez ${ }^{1}$, Ernesto Luciano Chagoyén ${ }^{2}$, José Fernando Martirena ${ }^{3}$}

${ }^{1}$ Oficina de Consultoría y Diseño, Empresa Nacional de Investigaciones Aplicadas a Construcciones, Calle 100, No. 9107, Entre Vento y 16, Boyeros, La Habana, Cuba, rafael@enia.co.cu

${ }^{2}$ Departamento de Ingeniería Civil, Facultad de Construcción, Universidad Central Marta Abreu de Las Villas, Carretera a Camajuaní, km 5 1⁄2, Santa Clara, Villa Clara, Cuba, chagoyen@uclv.edu.cu

${ }^{3}$ Centro de Investigaciones de Estructuras y Materiales de Construcción CIDEM, Facultad de Construcción, Universidad Central Marta Abreu de Las Villas, Carretera a Camajuaní, km 5 ̌ㅗ, Santa Clara, Villa Clara, Cuba, martirena@uclv.edu.cu

Cracking of concrete elements resulting from drying shrinkage is a phenomenon that affects a large number of structures built with this material worldwide. As a consequence, the buildings are not only affected aesthetically, but also structurally, since cracking patterns, in addition to affecting the element initial stiffness, acts as a pathway for atmospheric agents, contributing to the development of corrosion in reinforcing steel and, consequently, affects durability. This paper presents a characterization of the processes of development of strains due to the shrinkage in a set of representative samples of Cuban concretes. An evaluation of influencing factors in development of shrinkage processes, as well as effectiveness of different mitigation strategies, are considered. Results prove the relevance of the formation and composition of the microstructure and the coarse aggregate influence in shrinkage development. Effectiveness of tensile-active shrinkage reducing additives is assessed, among other solutions, resulting in the most effective mitigation strategy.

Keywords: drying shrinkage, deformations, microstructure, concrete, mitigation strategies
El agrietamiento de elementos de hormigón debido a retracción por secado afecta a un gran número de estructuras en todo el mundo. Como consecuencia, los edificios no solo se afectan estéticamente, sino también estructuralmente, ya que los patrones de fisuración, además de afectar la rigidez inicial, actúan como un camino a los agentes atmosféricos, contribuyendo a la corrosión del acero de refuerzo y, consecuentemente afectan la durabilidad. Se presenta una caracterización de la retracción para un conjunto de muestras de hormigones producidos en Cuba. Se evalúan factores que influyen en el desarrollo de los procesos de retracción, así como la efectividad de las diferentes estrategias de mitigación. Los resultados demuestran la relevancia de la formación y composición de la microestructura y la influencia de los áridos gruesos en el desarrollo de la retracción. La eficacia de los aditivos reductores de la retracción también se devela como la estrategia de mitigación más efectiva.

Palabras clave: retracción por secado, deformaciones, microestructura, hormigón, estrategias de mitigación

\section{Introduction}

Numerous studies have considered shrinkage of the paste from the cementitious materials as the fundamental cause of volume change in the concrete (e.g. Gribniak et al., 2008). There are three fundamental types of shrinkage: chemical shrinkage, autogenous shrinkage and drying shrinkage, being the last one, as proposed by Eguchi and Teranishi (2005) and numerous other authors, the main cause of shrinkage and cracking processes on statically indeterminate structures. Drying shrinkage cracking in such concrete structures has become one of the principal causes of degradation in concrete constructions (Pan et al., 2016). 
There are many factors influencing the development of drying shrinkage, however, in literature, the most influencing three factors are: existence of relative humidity RH gradients, evolution of the pore microstructure of cementitious paste, and aggregate-paste interface (Bissonnette et al., 1999; Liu et al., 2016).

Relationship between the development of drying shrinkage and changes in $\mathrm{RH}$ of the elements is a property of the material, applicable to any type or constraint conditions of a concrete member (Jafarifar et al., 2014). Therefore, the free shrink deformations (shrinkage due to drying) are mostly expressed as a non-linear relation of the drying function of the samples (RH variation), which is detailed in ACI-209R (1998) and ACI-231 (2008). According to these sources, other parameters of the mixtures such as water/ cement $\mathrm{w} / \mathrm{c}$ ratio, composition ratios between the different types of aggregates and consistency of the mixture, are also influencing on this dependency (Zhang et al., 2012).

The importance of the aggregate-paste interface as shown by Sun et al. (2001), lies mainly in the presence of the coarse aggregate and the restriction effect to the shrinkage provided to the cementitious matrix, which greatly reduces the shrinkage of the concrete, as showed by Fujiwara (2008) and Herrera an Ramírez (2014).

This paper shows, mainly in concrete samples, a comparative analysis on the development of the shrinkage between hardened samples of concrete, mortars and pastes. In these studies, values of the deformations by effects of drying became significantly smaller, due to constriction effect induced by the presence of coarse aggregate.

It is known that capillary porosity is a factor that severely affects the drying shrinkage (Helmuth and Turk, 1967; Verbeck and Helmuth, 1969), and directly depends on the formation of the microstructure of cementitious paste, which directly influences the final development of shrinkage strains. Therefore, in order to reduce the effects of shrinkage, it is important to modify the pore structure of the cementitious matrix, for which (Juenger and Jennings, 2002) proposes to control composition of the paste, curing temperature and chemical and mineral composition of the additions used.

The increase in the occurrence of cracks in concrete elements due to volume changes has led to the development of innovative methods to mitigate this process. There are different methods, such as internal curing, pozzolanic additions, use of expansive cements and use of shrinkage reducing admixtures SRAs (ACI-231, 2008).

This paper aims to carry out practical studies and tests, to characterize the development of the drying shrinkage processes in concretes with compressive strength of approximately $30 \mathrm{MPa}$ for structural uses, produced in Cuba. Additionally, the effectiveness of different mitigation techniques is assessed for seeking the best strategy to reduce the effects of the drying shrinkage for concrete structures in Cuba.

\section{Experimental programme}

The experimental programme aims to evaluate the process of drying shrinkage in concretes by monitoring deformations generated in samples composed of cementitious materials.

It is evaluated the effects of the action of the main influencing factors in development of the drying shrinkage on samples. Main factors taken into account are variation of the relative humidity inside the samples, composition and typology of the aggregate - paste interface and the microstructural characteristics of the samples. It is considered as a useful tool, the approach of the microstructural characteristics of mixing, using the theoretical model of Powers (Brouwers, 2004). Finally, this paper presents an assessment on several proposed drying shrinkage mitigation strategies, based on the obtained characterization, and also effectiveness of each one.

Assessed mitigation strategies are: 1) use of reducing shrinkage additives, for samples produced using a commercial additive (Shrinko-tec-nano-4), and 2) addition of zeolitic active pozzolans (supplementary cementitious materials, SCM).

\section{Materials}

The cement used to elaborate samples corresponds to Siguaney Factory SF, located in the central region of Cuba. Tables 1 and 2 summarize physical and chemical properties of this cement. 
The degree of hydration of the cement was determined in (Fernandez, 2008) by scanning image processing on an electronic microscopy (Figure 1). The determined cement degree of hydration was $\alpha=84.0 \%$ at 28 days of setting.

Table 1: Physical-mechanical characteristics of the used cements

\begin{tabular}{|l|c|}
\hline Property & $\begin{array}{c}\text { Cement } \\
\text { Siguaney } \\
\text { SF }\end{array}$ \\
\hline Initial setting time, min & 150 \\
\hline Final setting time, min & 260 \\
\hline Normal consistency, \% & 24.6 \\
\hline Ground fineness, \% & 6.5 \\
\hline Real specific weight, $\mathrm{g} / \mathrm{cm}^{3}$ & 3.08 \\
\hline Resistance to compression 7 days, $\mathrm{MPa}$ & 8.6 \\
\hline Resistance to compression 28 days, $\mathrm{MPa}$ & 42.4 \\
\hline
\end{tabular}

Table 2: Chemical characteristics of the used cement

\begin{tabular}{|c|c|c|c|c|c|c|}
\hline \multicolumn{7}{|c|}{ Chemical composition of Siguaney cement } \\
\hline $\begin{array}{l}\text { Oxides, } \\
\text { \% weight }\end{array}$ & $\mathrm{SiO}_{2}$ & $\mathrm{Al}_{2} \mathrm{O}_{3}$ & $\mathrm{Fe}_{2} \mathrm{O}_{3}$ & $\mathrm{CaO}$ & $\mathrm{MgO}$ & $\mathrm{SO}_{3}$ \\
\hline & 22.03 & 4.85 & 3.23 & 60.58 & 1.65 & 3.00 \\
\hline $\begin{array}{l}\text { Oxides, } \\
\% \text { weight }\end{array}$ & $\mathrm{Na}_{2} \mathrm{O}$ & $\mathrm{K}_{2} \mathrm{O}$ & $\mathrm{TiO}_{2}$ & LOI & Total & $\begin{array}{c}\text { Alcalines, } \\
\% \mathrm{Na}_{2} \mathrm{O}\end{array}$ \\
\hline & 0.3 & 0.62 & 0.25 & 3.31 & 10 & 0.71 \\
\hline
\end{tabular}
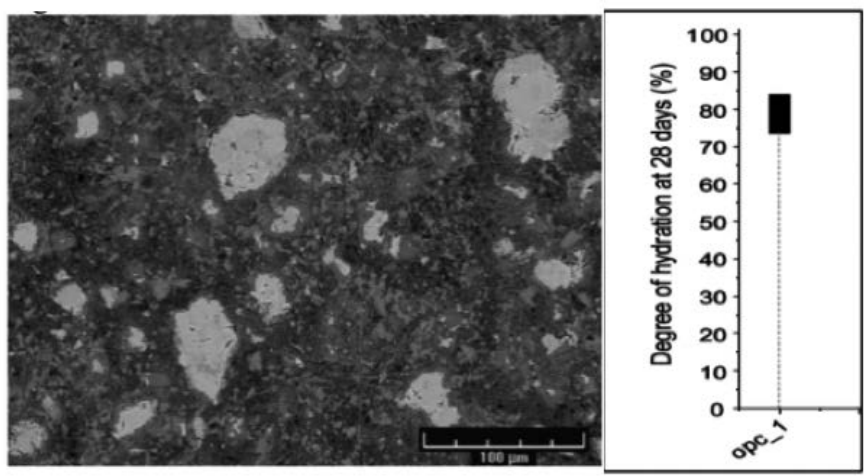

Figure1: Image of the microstructure 28 days after the setting of the cement paste (Fernandez, 2008)

Aggregates play an important role in restraining the shrinkage of the cement matrix, which could reduce concrete shrinkage compared to plain hardened cement paste. Additionally, aggregates confine the volumetric change of concrete. Physical and chemical characteristics of these aggregates play a fundamental role in the development of the drying shrinkage in the concrete specimens. Tables 3, 4 and 5 summarize the physical and chemical characteristics of the fine aggregate used in this investigation.

Table 3: Characteristics of fine aggregates

\begin{tabular}{|l|c|c|}
\hline \multirow{2}{*}{ Property } & \multicolumn{2}{|c|}{ Quarry } \\
\cline { 2 - 3 } & Arimao & Purio \\
\hline Current specific weight, $\mathrm{g} / \mathrm{cm}^{3}$ & 2.66 & 2.63 \\
\hline Saturated specific weight, $\mathrm{g} / \mathrm{cm}^{3}$ & 2.68 & 2.64 \\
\hline Apparent specific weight, $\mathrm{g} / \mathrm{cm}^{3}$ & 2.69 & 2.72 \\
\hline Loose unit weight, $\mathrm{kg} / \mathrm{m}^{3}$ & 1530 & 1536 \\
\hline Compressed unit weight, $\mathrm{kg} / \mathrm{m}^{3}$ & 1639.8 & 1698 \\
\hline Absorption, \% & 0.3 & 1.24 \\
\hline Material thinner than $0.075 \mathrm{~mm}, \%$ & 0 & 0 \\
\hline Clay lumps, \% & 0 & 0.15 \\
\hline \% of holes, \%) & 37.1 & 36.3 \\
\hline Maximum size, $\mathrm{mm}$ & 9.52 & 9.52 \\
\hline
\end{tabular}

Table 4: Granulometry of fine aggregates \% passing

\begin{tabular}{|c|c|c|}
\hline Sieve, $\mathrm{mm}$ & Arimao & El Purio \\
\hline 9.52 & 99.5 & 100 \\
\hline 4.76 & 96 & 96 \\
\hline 2.38 & 87 & 73 \\
\hline 1.19 & 66 & 47 \\
\hline 0.59 & 36 & 25 \\
\hline 0.297 & 16 & 15 \\
\hline 0.149 & 3 & 6 \\
\hline
\end{tabular}

Table 5: Chemical composition of the fine aggregates in $\%$

\begin{tabular}{|l|c|c|}
\hline Parameter & Arimao & Purio \\
\hline Silicon dioxide $\mathrm{SiO}_{2}$ & 66.89 & 0.95 \\
\hline Ferric oxide $\mathrm{Fe}_{2} \mathrm{O}_{3}$ & 10.09 & 1.91 \\
\hline Aluminum oxide $\mathrm{Al}_{2} \mathrm{O}_{3}$ & 13.23 & 3.92 \\
\hline Calcium oxide $\mathrm{CaO}$ & 4.96 & 50.53 \\
\hline Magnesium oxide $\mathrm{MgO}$ & 1.39 & 0.19 \\
\hline Sulfur trioxide $\mathrm{SO}_{3}$ & 0.04 & 0.02 \\
\hline Lost by Ignition PPI & 2.31 & 42.89 \\
\hline Insoluble Residue RI & 92.16 & 1.11 \\
\hline Total Carbonates CT & 11.91 & 90.18 \\
\hline
\end{tabular}

Tables 6, 7 and 8 summarize the physical and chemical characteristics of the coarse aggregate used in this investigation. 
Table 6: Characteristics of coarse aggregates

\begin{tabular}{|c|c|c|c|c|}
\hline & \multicolumn{4}{|c|}{ Quarry } \\
\hline Property & $\begin{array}{l}\frac{\tilde{0}}{\tilde{E}} \\
\frac{\tilde{\omega}}{\pi} \\
\end{array}$ & $\stackrel{D}{\doteq}$ & 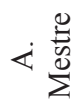 & $\stackrel{0}{\Xi}$ \\
\hline Current specific weight, $\mathrm{g} / \mathrm{cm}^{3}$ & 2.58 & 2.52 & 2.58 & 2.53 \\
\hline Saturated specific weight, $\mathrm{g} / \mathrm{cm}^{3}$ & 2.64 & 2.58 & 2.61 & 2.58 \\
\hline Apparent specific weight, $\mathrm{g} / \mathrm{cm}^{3}$ & 2.73 & 2.67 & 2.65 & 2.66 \\
\hline Loose unit weight, $\mathrm{kg} / \mathrm{m}^{3}$ & 1493 & 1282 & 1385 & 1404 \\
\hline Compressed unit weight, $\mathrm{kg} / \mathrm{m}^{3}$ & 1727 & 1486 & 1543 & 1508 \\
\hline Absorption, $\%$ & 2.81 & 2.55 & 1.05 & 2,00 \\
\hline Flat and extended particles, $\%$ & 0.60 & 3.16 & 0.20 & 6.10 \\
\hline Clay lumps, \% & 0.13 & 0,00 & 0,00 & 0.10 \\
\hline$\%$ of holes & 34.30 & 38.84 & 40.20 & 39.20 \\
\hline Maximum size, $\mathrm{mm}$ & 19.1 & 19.1 & 19.1 & 19.1 \\
\hline
\end{tabular}

Table 7: Granulometry of coarse aggregates \% passing

\begin{tabular}{|c|c|c|c|c|}
\hline Sieve, $\mathrm{mm}$ & Yigre & El Purio & Algaba & A.Mestre \\
\hline 25.4 & 100 & 100 & 100 & 100 \\
\hline 19.1 & 98 & 98 & 91 & 98 \\
\hline 12.7 & 98 & 57 & 34 & 57 \\
\hline 9.52 & 42 & 25 & 11 & 25 \\
\hline 4.76 & 24 & 4 & 6 & 4 \\
\hline 2.38 & 16 & 2 & 6 & 2 \\
\hline 1.19 & 0 & 1 & 0 & 1 \\
\hline 0.07 & 0 & 0 & 0 & 0 \\
\hline
\end{tabular}

Table 8: Chemical composition of the coarse aggregates in $\%$

\begin{tabular}{|l|c|c|c|}
\hline Parameter & Algaba & Purio & Yigre \\
\hline Silicon dioxide $\mathrm{SiO}_{2}$ & 61.23 & 0.95 & 0.20 \\
\hline Ferric oxide $\mathrm{Fe}_{2} \mathrm{O}_{3}$ & 7.08 & 1.91 & 1.91 \\
\hline Aluminum oxide $\mathrm{Al}_{2} \mathrm{O}_{3}$ & 11.73 & 3.92 & 3.92 \\
\hline Calcium oxide $\mathrm{CaO}$ & 5.97 & 50.53 & 50.53 \\
\hline Magnesium oxide $\mathrm{MgO}$ & 3.77 & 0.19 & 0.19 \\
\hline Sulfur trioxide $\mathrm{SO}_{3}$ & 0.04 & 0.02 & 0.06 \\
\hline Lost by Ignition $\mathrm{PPI}$ & 4.53 & 42.89 & 42.84 \\
\hline Insoluble Residue RI & 85.70 & 1.11 & 0.74 \\
\hline Total Carbonates CT & 17.91 & 90.18 & 90.18 \\
\hline
\end{tabular}

Tables 12 and 13 show proportions used for sample preparation. To mitigate drying shrinkage, mineral additions and chemical admixtures were used. These include the use of commercially available Shrinko-Tec Nano 4 SRAs and zeolite from reservoirs located in the province of Villa Clara, which substitute $15 \%$ of volume of the cement of the original dosage.
Shrinko-Tec Nano 4 is a liquid formulated and conceived to act on mechanisms, which generate concrete shrinkage. It does not contain expansive agents nor chlorides either. It acts with chemical - physical functionality and improves quality of conglomerates, reducing the shrinkage up to $80 \%$ for short ages and up to more than $50 \%$ for long ages (non-constrained shrinkage according to ASTM C157, 2006).

In addition, as part of the materials used in the dosages studied, two types of super fluidifying additives were used. These were Mapefluid N-100 and the Dynamon SX. Mapefluid N-100 is a super-fluidifying additive for high quality concrete. It is an aqueous solution with $34.5 \%$ active polymer, which is capable of spreading the cement grains of the concrete mixture, allowing in this way to confer excellent workability to the mixture.

Dynamon SX is an additive with an acrylic base modified for concrete, belonging to MAPEI's new super-plasticizing additives system. It is a $23 \%$ aqueous solution of acrylic polymer, which efficiently disperses cement grains of mixture. It is also able to favour a slow setting process of the mixture, producing the delay of the hydration of the cement and in this way confers a longer period of workability to the mixture. Manufacturer's technical specifications, mentioned above, provide properties of the chemical additive.

The zeolite used in this investigation comes from the Tasajeras deposit, located in San Juan de las Yeras, province of Villa Clara and is called ZEOMICRO. Table 9 describes its physical - mechanical characteristics. The zeolite has a chemical structure similar to a cage, consisting of tetrahedral of $\mathrm{SiO}_{4}$ and $\mathrm{AlO}_{4}$ joined by shared oxygen atoms. The negative charges of the $\mathrm{AlO}_{4}$ units are in balance by the presence of interchangeable cations, notably calcium, magnesium, sodium, potassium and iron. Other substances, for example heavy metals and ammonia ions can displace these ions. This phenomenon is known as cation exchange, and it is this ability of the clinoptilolite that gives it the useful properties. Clinoptilolite is also known as adsorbent of certain gases, such as hydrogen sulfide and the sulfur dioxide. 
Table 9: Characteristics of the zeolite

\begin{tabular}{|l|c|}
\hline \multicolumn{2}{|l|}{ Property Value } \\
\hline Current specific weight, $\mathrm{g} / \mathrm{cm}^{3}$ & 1.81 \\
\hline Saturated specific weight, $\mathrm{g} / \mathrm{cm}^{3}$ & 2.02 \\
\hline Apparent specific weight, $\mathrm{g} / \mathrm{cm}^{3}$ & 2.30 \\
\hline Loose unit weight, $\mathrm{kg} / \mathrm{m}^{3}$ & 1076 \\
\hline Compressed unit weight, $\mathrm{kg} / \mathrm{m}^{3}$ & 1249 \\
\hline Absorption, $\%$ & 11.66 \\
\hline Material thinner than $0.075 \mathrm{~mm}, \%$ & 20.81 \\
\hline Clay lumps, $\%$ & 0.0 \\
\hline$\%$ of holes & 31.03 \\
\hline Fineness modulus & 1.65 \\
\hline
\end{tabular}

\section{Specimens}

For assessment of development of shrinkage deformations in concrete samples, 14 concrete samples, organized into two sets, were prepared. The specimens were cast using concrete produced at an industrial batching plant, taking into account both, the concrete and the mortar samples the corresponding adjustments in volumes of the materials as a function of the absorption and the state of humidity of the aggregates used in the samples.

Three mortar samples, which correspond in their formulation, with some of the concrete samples, differing only in the absence of the coarse aggregate in mortar samples, evaluated the influence of the presence of coarse aggregate, in developing of shrinkage by drying.

Two sets of concrete samples were differentiated:

Set 1: samples with similar type of fine aggregate FA and type of cement, varying origin of coarse aggregate CA. Mixtures assessed the effects of the variation of the compactness, porosity and origin of aggregates, as well. A series of four samples composes this set of samples, made with cement from the Siguaney factory, fine aggregates from Arimao quarry and coarse aggregates from Algaba, El Yigre and Armando Mestre quarries (Table 10).

Table 10: Component of Set 1 samples

\begin{tabular}{|c|c|c|c|c|c|}
\hline $\begin{array}{c}\text { Sample } \\
\text { Id. }\end{array}$ & Cement & $\begin{array}{c}\text { Fine } \\
\text { aggre- } \\
\text { gate }\end{array}$ & $\begin{array}{c}\text { Coarse } \\
\text { Aggre- } \\
\text { gate }\end{array}$ & $\begin{array}{c}\text { Relation- } \\
\text { ship } \\
\text { w/c }\end{array}$ & $\begin{array}{c}\text { Relation- } \\
\text { ship, \% } \\
\text { FA/CA }\end{array}$ \\
\hline MHT-1 & CF & Arimao & Yigre & 0.45 & $40-60$ \\
\hline MHT-2 & CF & Arimao & Yigre & 0.45 & $40-60$ \\
\hline MHT-3 & CF & Arimao & A Mestre & 0.45 & $40-60$ \\
\hline MHT-4 & CF & Arimao & Algaba & 0.45 & $40-60$ \\
\hline
\end{tabular}

Set 2: samples with common dosage, assessing the effect of addition of different shrinkage reducing admixtures. Eight concrete samples, with same dosage, using cement from Siguaney factory and aggregates from El Purio quarry were prepared, with w/c and FA/CA ratio of 0.40 and $52 \%$ / 48\%, respectively (Table 11 ).

Table 11: Concrete samples used for the evaluation of different variants of shrinkage mitigation

\begin{tabular}{|c|c|c|c|}
\hline No. & $\begin{array}{c}\text { Sample } \\
\text { Id. }\end{array}$ & Type of addition & Observations \\
\hline 1 & MHT-8 & Any & Comparison pattern \\
\hline 2 & MHT-9 & Shriko-Tec Nano 4 & Low dose \\
\hline 3 & MHT-10 & Shriko-Tec Nano 4 & Maximum dose \\
\hline 4 & MHT-11 & $\begin{array}{c}\text { Shriko-Tec Nano 4 } \\
\text { N-100 }\end{array}$ & Maximum dose \\
\hline 5 & MHT-12 & $\begin{array}{r}\text { Shriko-Tec Nano 4 } \\
\text { N-100 }\end{array}$ & Maximum dose \\
\hline 6 & MHT-13 & $\begin{array}{r}\text { Shriko-Tec Nano 4 } \\
\text { Sx-32 }\end{array}$ & Maximum dose \\
\hline 7 & MHT-14 & $\begin{array}{r}\text { Shriko-Tec Nano 4 } \\
\text { Sx-32 }\end{array}$ & Maximum dose \\
\hline 8 & MHT-16 & Use of Zeolite & Replacing the 15\% \\
\hline
\end{tabular}

Table 12: Proportions of materials in concrete mixtures

\begin{tabular}{|c|c|c|c|}
\hline $\begin{array}{c}\text { Sample } \\
\text { Id. }\end{array}$ & $\begin{array}{c}\text { Cement mass, } \\
\mathrm{kg} / \mathrm{m}^{3}\end{array}$ & $\begin{array}{c}\text { Water mass, } \\
\mathrm{kg} / \mathrm{m}^{3}\end{array}$ & $\begin{array}{c}\text { Fine } \\
\text { aggregate } \\
\text { quarrry }\end{array}$ \\
\hline MHT-1 & 493 & 195 & Arimao \\
\hline MHT-2 & 519 & 195 & Arimao \\
\hline MHT-3 & 539 & 200 & Arimao \\
\hline MHT-4 & 558 & 190 & Arimao \\
\hline $\begin{array}{c}\text { MHT-8 to } \\
\text { MHT -16 }\end{array}$ & 390 & 168 & Purio \\
\hline $\begin{array}{c}\text { Sample } \\
\text { Id. }\end{array}$ & $\begin{array}{c}\text { Fine } \\
\text { mass, } \mathrm{kg} / \mathrm{m}^{3}\end{array}$ & $\begin{array}{c}\text { Coarse } \\
\text { aggregate } \\
\text { quarry }\end{array}$ & $\begin{array}{c}\text { Coarse } \\
\text { aggregate } \\
\text { mass, } \mathrm{kg} / \mathrm{m}^{3}\end{array}$ \\
\hline MHT-1 & 680 & Yigre & 1005 \\
\hline MHT-2 & 680 & Yigre & 1005 \\
\hline MHT-3 & 680 & A.Mestre & 1005 \\
\hline MHT-4 & 680 & Algaba & 1005 \\
\hline $\begin{array}{c}\text { MHT-8 to } \\
\text { MHT -16 }\end{array}$ & 967 & Purio & 874 \\
\hline
\end{tabular}

Samples with Shriko-Tec Nano 4 additive SRAs, cover the full range of application of product concentrations, including minimum and maximum dosage $(0.5 \%-1.5 \%$ by weight, relative to the weight of the cement). In addition, 
compatibility of this additive with super-fluidifying additives of types N100-RC and Dynamón Sx-32 is verified. Finally, sample is made with the use of zeolite from Tasajeras quarry in San Juan de las Yeras, province of Villa Clara, which substitute a $15 \%$ of cement volume of the original dosage. These samples and corresponding freeof-additives patterns in their composition are compared each other's. Table 12 shows dosages or proportions of materials used in concrete samples preparations in both set of samples groups. Cement type used was SF in all cases.

Mortars samples are organized as follows: pattern sample, sample including zeolite and $\mathrm{w} / \mathrm{c}=0.55$ and addition of shrinkage reducing additive. Table 13 shows dosages or proportions of materials used for $1 \mathrm{~m}^{3}$ of mortar samples.

Additionally, Table 14 summarizes the samples of both investigations (concrete and mortar samples) which are compatible for a comparative analysis of shrinkage deformations. Selected samples are those corresponding in their formulation, differing only in the absence of coarse aggregate in the mortar samples.

Table 13: Proportions of materials in mortars mixtures

\begin{tabular}{|c|c|c|c|}
\hline $\begin{array}{l}\text { Sample } \\
\text { Id. }\end{array}$ & $\begin{array}{c}\text { Cement mass, } \\
\text { kg }\end{array}$ & $\begin{array}{l}\text { Zeolite mass, } \\
\text { kg }\end{array}$ & $\begin{array}{c}\text { Water mass, } \\
\mathrm{kg}\end{array}$ \\
\hline MM1 & 390.0 & 0.0 & 190.0 \\
\hline MM5 & 331.5 & 34.4 & 163.0 \\
\hline MM10 & 390.0 & 0.0 & 167.7 \\
\hline $\begin{array}{l}\text { Sample } \\
\text { Id. }\end{array}$ & $\begin{array}{c}\text { Fine } \\
\text { Aggregate } \\
\text { mass, kg }\end{array}$ & $\begin{array}{c}\mathrm{w} / \mathrm{c} \\
\text { (water to } \\
\text { binder ratio) }\end{array}$ & \\
\hline MM1 & 902.0 & 0.49 & \\
\hline MM5 & 680.0 & 0.45 & \\
\hline MM10 & 1005.5 & 0.43 & \\
\hline
\end{tabular}

All evaluated samples are under different RH regimes, to evaluate the influence of this variable on shrinkage deformations. $\mathrm{RH}$ regimes consist of placing specimens at $\mathrm{RH}=100 \%$ conditions, by its immersion in a curing tank by 24 hours. Afterwards, samples are placed in an oven, with controlled-RH $=70 \%$ and constant temperature of $30^{\circ} \mathrm{C}$, until the samples arrive to constant weight (7 days). Then, samples are set to $\mathrm{RH}=45 \%$ conditions, and temperature of $25^{\circ} \mathrm{C}$ in a controlled temperature room (7 days).
Table 14: Correspondence between mortar and concrete samples

\begin{tabular}{|c|c|c|}
\hline Concrete sample Id. & $\begin{array}{c}\text { Dosage } \\
\text { similar to }\end{array}$ & Mortar sample Id. \\
\hline MHT-1 & $\approx$ & MM1 \\
\hline MHT-8 & $\approx$ & MP Ar \\
\hline MHT-2 & $\approx$ & MM5 \\
\hline
\end{tabular}

MP Ar is the pattern sample of mortars dosages with use of SRAs

\section{Test procedures \\ Shrinkage test}

Procedure for measurement of deformation due to drying shrinkage adopted in correspondence with (ASTM-C157, 2006), however it was decided to show values of shrinkage as in international literature in $\mu$ strain, unlike the ASTM that expresses them in \%. For measurements on the upper and lower faces of the testing pieces, fixed measuring points are placed, as constant references for performing length change measurements. At $231 / 2 \pm 1 / 2$ hours of concreting, the specimens must be stripped and measured for the first time. It is then, submerged in a 28-day curing vessel, for their length monitoring.

Measurements are performed in-between 8:00 AM - 9: 30 AM to minimize the effect of the ambient conditions, so no significant impact on stability of samples occurs. Samples should not remain more than 35 minutes outside the conditions of temperature and relative humidity to which they are exposed.

\section{Estimation of microstructural characteristics using the Powers model}

Powers and Brownyard (Brouwers, 2004) were the first to investigate systematically the reaction of cement and water and the composition of cement paste. This model is still valid, especially when Portland cement with high clinker content is used, such as in this case. The concept of non-evaporable water and gel is introduced. Their specific volumes are inferior to those of the free water, explaining the causes of the chemical contraction. The retained water is related to the content of the four most abundant clinker phases, namely: alite, belite, aluminate and ferrite.

The model addresses important aspects, such as the specific volume of non-evaporable water and gel, as well as the 
question of water being "compressed". Subsequently, it will be demonstrated that its water retention data allows the study of the molar reactions of the calcium silicates and the reaction products $\mathrm{C}-\mathrm{S}-\mathrm{H}$ and $\mathrm{CH}$, representing a major innovation.

Saturated C-S-H density and its porosity obtained using the molar reactions and the specific volumes of nonvaporizable water and gel, could help explaining the mechanism behind shrinkage.

Powers and Brownyard (Brouwers, 2005) model is used for characterization of pore microstructure of studied samples, which allows a quantitative estimation of the volumes of hydration products of cement paste, adopting as variables the degree of hydration $\alpha$ - fraction of hydrated cement and non-evaporable water. This model, as highlighted by Brouwers $(2004,2005)$, distinguishes three phases in cement paste: capillary pores, unreacted cement and hydration products. The products of hydration include the products resulting from the hydration of the different phases of the clinker, as well as the space existing in the gel pores. Specifically, the use of expressions provided by the model for determination of the non-resistant compounds of the concrete mixtures, allows an approximated estimation of the total volume of paste in the mixture, the volumes of porosity, capillary water and volume of missing paste of the analyzed mixtures. For those purposes, the following expressions are used:

- Total volume of paste in the mixture $T_{v p}$ :

$$
T_{v p}=V_{\text {cem }}+V_{\text {water }}+V_{\text {fines }}
$$

- Volume of contraction pores :

$$
V_{p c}=\alpha\left(0.254 V_{h c}\right)
$$

where $\alpha$ is the cement hydration degree, $V_{h c}$ is the water required for hydration.

$$
\begin{aligned}
& \text {-Volume of capillary water } V_{h l} \text { : } \\
& V_{h l}=\frac{w}{c}-\alpha V_{h c}-V_{h g e l}
\end{aligned}
$$

where $V_{h c}$ is the water required for hydration, w/c is the water-cement relationship, $V_{\text {hgel }}$ is the gel water volume.

- Volume of missing paste :

$$
V_{f p}=V_{\text {voids }}-V_{\text {paste }}
$$

where $V_{\text {voids }}$ is the void volume of the cement matrix, $V_{\text {paste }}$ is the volume of paste in cement matrix.

The authors adopted a value of the degree of hydration of the cement $\alpha$ from Fernandez (2008) and carried out a complete characterization of the type of cement used. In addition, degree of hydration of the cement was determined by image processing to the results of the application of electronic microscopy scanning, being determined as degree of hydration of the cement: $\alpha=84.0 \%$ at 28 days of setting (Fernandez, 2008).

\section{Results and discussion}

\section{Results of the shrinkage measurements}

Figure 2 presents results of measured strain obtained on samples of Group 1, following the procedure described in ASTM C157 (2006).

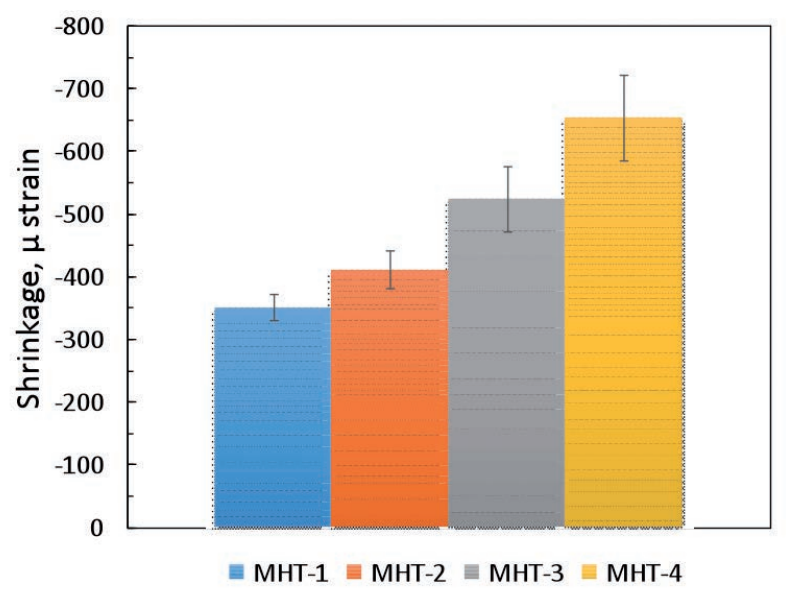

Figure 2: Behaviour of maximum deformations for group 1

As can be observed in Figure 2, development of remarkable deformation values was registered, which considerably exceed $150 \mu$-strain, recommended in ACI-231 (2008) as deformation threshold for cracking.

On the other hand, Figures 3 and 4 present the results of measurements made in Set-2-samples and mortar samples respectively, following the procedure described in ASTM C157 (2006), also for mortar samples. 


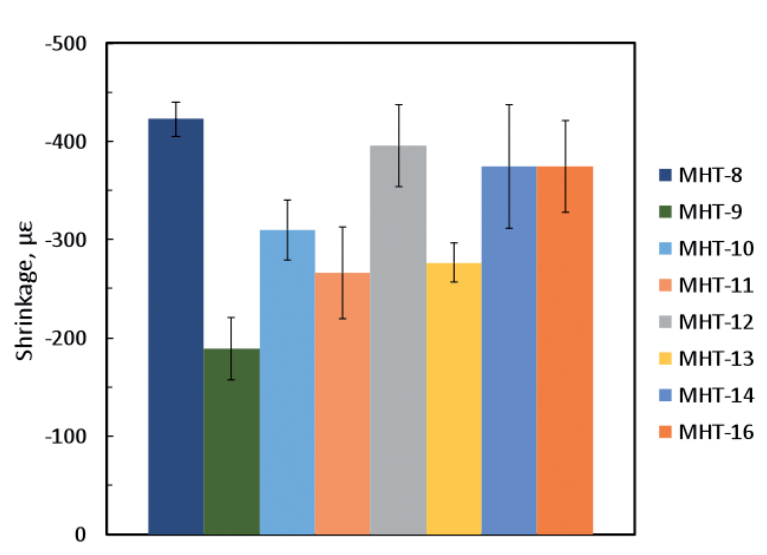

Figure 3: Behaviour of the maximum deformations for Group 2-samples

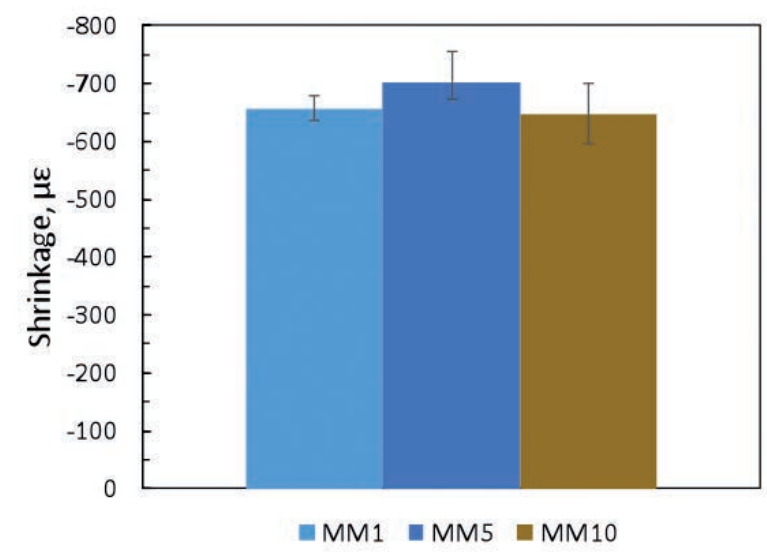

Figure 4: Behaviour of the maximum deformations for mortarssamples

\section{Influence of the type of coarse aggregate on drying shrinkage deformations}

Analysis of results of Set-1 samples shows that there are statistically, significant differences on the shrinkage values of each one of the analyzed samples. This proves that the type of coarse aggregate determines the magnitude of the drying shrinkage of the concrete samples studied. The different origin of the arid (quarries) in the samples, therefore the surface roughness, adsorption of moisture, shape of the particles and other factors that influence the paste-arid interface change, points to shrinkage deformation changes.

In order to show that the influence of the coarse aggregate type, parameters as quantity and type of cement, and fine aggregate materials were kept constant in samples. In the same way, water/cement $\mathrm{w} / \mathrm{c}$ and aggregate/cement ratios were kept constant.
The importance on the variation in the type of coarse aggregate could be explained through the severe variations in the characteristics of the pore matrix of samples, the volume of pores of the samples and in the sample concentrations of paste; all caused by changes in aggregates (Bentz and Jensen, 2004).

A similar evaluation was made on mortar-samples having mix proportioning, similar to those of concrete mixtures studied in the present investigation. The differences can clarify the impact of coarse aggregates on the shrinkage of concrete, moreover the reduction effect due to the presence of coarse aggregates in mixtures. This is consistent with results presented by Rao (2000). Values of shrinkage deformations experienced by each sample were grouped according to each of the levels of the factor evaluated as shown in Figure 5.

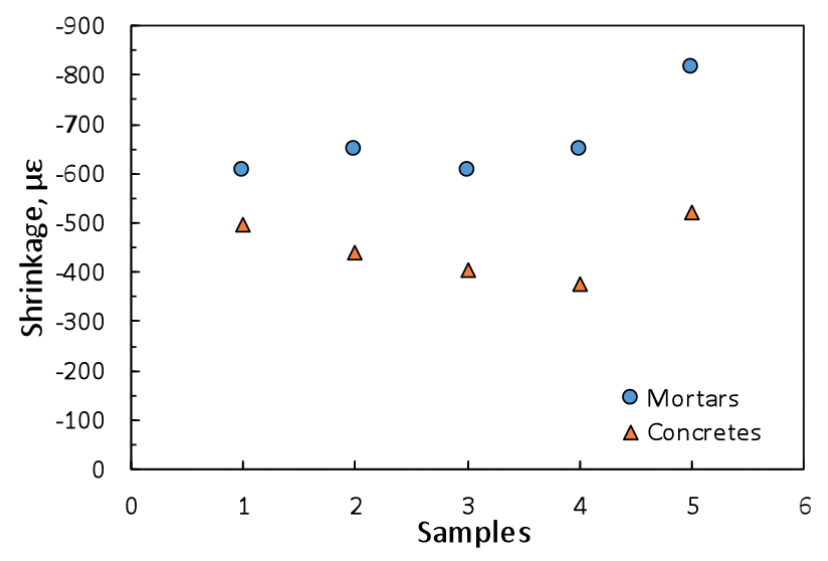

Figure 5: Shrinkage comparison between strains values obtained in mortar and concrete samples

These results confirm, with statistical significance, that deformations produced by drying the concrete samples are lower than those produced in mortar samples. This is confirmed by Bouhamou et al. (2013) and Rao (2000). Impact can be as high as $48 \%$, when evaluating the effect of coarse aggregate on concrete deformations induced by drying. These results show the important role that coarse aggregates could play in reducing the development of drying shrinkage in concrete structural members.

It is important to point out, that from the studied types of coarse aggregate, the Algaba's quarry is associated with the concretes that experimented the greatest development of shrinkage (with a difference of $35 \%$ of the reference standard sample), so it is evaluated as the aggregate with 
the least restrictive capacity against shrinkage. While aggregates from Armando Mestre and El Yigre quarries show the best moderating effect of shrinkage, achieving concretes with $16 \%$ decrease of shrinkage with respect to the reference standard sample.

\section{Influence of the total amount of paste on mixtures in drying shrinkage}

The volume of paste in concrete mixtures is generally much lower than in mortar (Bouhamou et al., 2013), and it is mainly focused on the phenomenon of shrinkage and not on the skeleton of coarse aggregate, which on the contrary, obstructs the development of this process.

That is why an analysis must be carried out between the proportion of paste volume in the mixture and the development of the shrinkage deformations, since the volume of paste in the mixture is moderately a governing factor in the reaction process of the cementitious materials (Bouhamou et al., 2013; Güneyisi et al., 2008).

Another important factor influencing the amount of paste in concretes is the formation of the skeleton of samples, precisely the common distance covered between two adjacent coarse aggregates, called the maximum thickness of the paste (Fujiwara, 2008). This property not only influences the shrinkage, but also the development of compressive strength, which reflects the influence of topology of the skeleton, establishing that the shorter the distance, the higher the performance of the concrete. Therefore, it is assumed that a minimum volume of paste supports this condition (Sant, 2009).

Figure 6 presents results obtained from the comparative process, between the values of shrinkage deformations and the values of total paste concentrations in samples, determined according to the procedures proposed in (Howland, 2012). In this procedure, the volume of paste of the mixture is the volume sum of the cementing material, the fine aggregates with maximum size less than $0.59 \mathrm{~mm}$ and the water in the mixture, according to (1). It clearly shows perceptible dependence relations, which corroborate good correlation levels ( $\mathrm{R}^{2}$ value) of fitting curves of data. As volume of paste in the mixtures increases (see Figure 5), values of shrinkage deformations decrease. These results are consisting with the findings of other authors, who confirm the direct relation of dependence existing between the volume of paste in samples and shrinkage deformations (Bissonnette et al., 1999; Güneyisi et al., 2008).

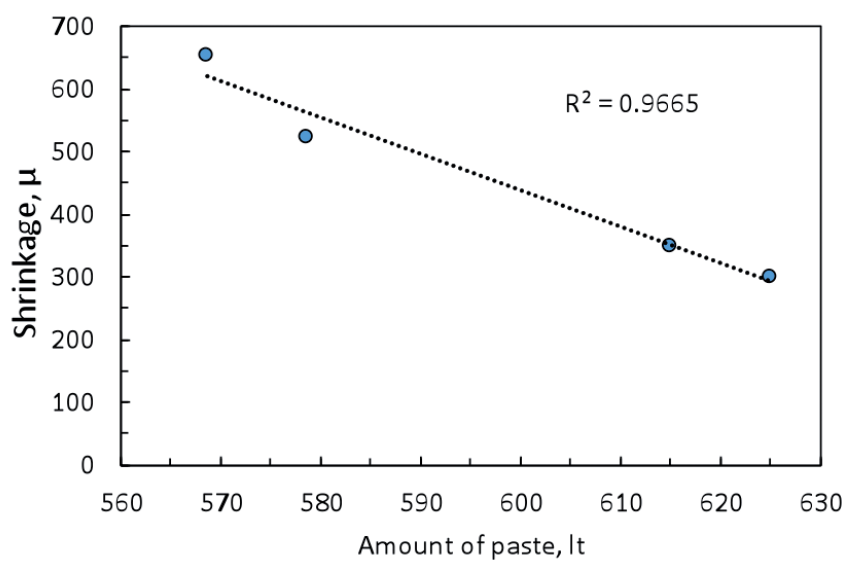

Figure 6: Relation between paste volume and shrinkage deformations

\section{Influence of the microstructure of samples in the evolution of the shrinkage}

The microstructure of cementitious materials is a property that evolves over time, influenced by many variables, such as temperature and relative humidity. The microstructure of these materials generally begins as an aqueous dispersion of a finely divided powder and aggregates of various sizes, until it evolves into a solid mass, formed by a porous matrix of interconnected solid products and aggregates inclusions (Segura et al., 2008). The development of many of its performance properties such as compressive strength, permeability, porosity, among others, depend on the microstructural characteristics of the materials.

It has been also proven, that refining the pore matrix of the samples brings about notable reductions in the development of shrinkage deformations that are achieved ( $\mathrm{Li}$ and Yao, 2001). Further, the pore structure of samples defines the evolution of the magnitudes of shrinkage. Additionally, Chen et al. (2013) can verify that the pore structure of the samples defines the evolution of the magnitudes of the retraction. The expression of Young-Laplace for the capillary tension $p_{c}$, physically summarizes it.

$$
p_{c}=\frac{2 \gamma_{w} \cos \theta_{w}}{r-t}
$$

Where $\theta_{w}$ is the contact angle in degrees, $\gamma_{w}$ is the surface 
tension of the pore solution in $\mathrm{N} / \mathrm{m}, r$ is the radius of the menisci in $\mathrm{m}$ and $t$ is the thickness of an adsorbed layer on the surface of the pore wall as shown in Figure 7. Expression (5) clearly shows the inverse relationship between the development of the porous structure and the retraction.

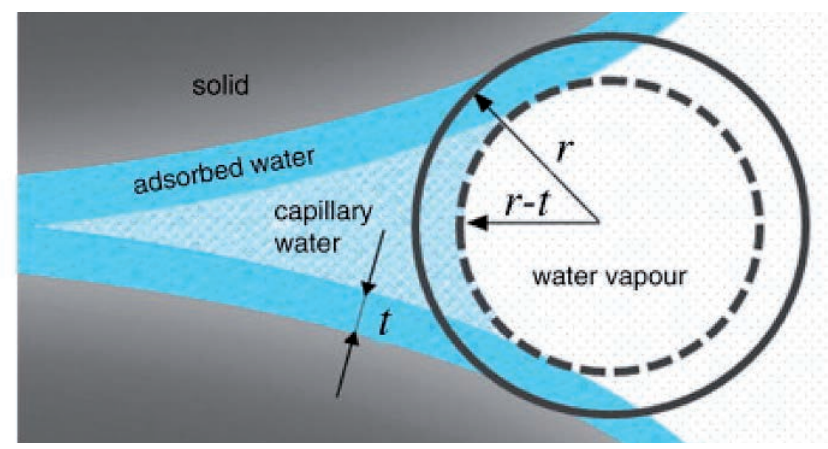

Figure 7: Schematic representation of menisci and adsorbed water layer in capillary pores (Chen et al., 2013)

After quantification of non-resistant compounds in samples, the evolution of different estimated microstructural parameters was monitored. Results are consistent with the findings of Juenger and Jennings (2002) and Sun et al. (2001). As porosity increases, values of shrinkage deformations increase proportionally. The inversely proportional relation existing between the capillary water and the shrinkage, denoted as Young-Laplace expression for capillary tensions computation has also been observed. It is possible to identify a directly proportional relation between the amount of missing paste and development of shrinkage deformations. Figures $8 \mathrm{a}, 8 \mathrm{~b}$ and $8 \mathrm{c}$ show the relation between shrinkage and contraction pores, volume of capillary water and volume of missing paste. As it can be observed, the shrinkage strains versus contraction pores relation is far from a linear correlation, unlike the rest of the relations.

\section{Shrinkage evolution according to the mitigation strategies evaluated}

An independent analysis on the contribution of shrinkage reduction by each separately variant, it allows concluding that, zeolite achieves around $11 \%$ of shrinkage reduction as shown in Figure 9.

Contribution of the lime-pozzolan mineral addition

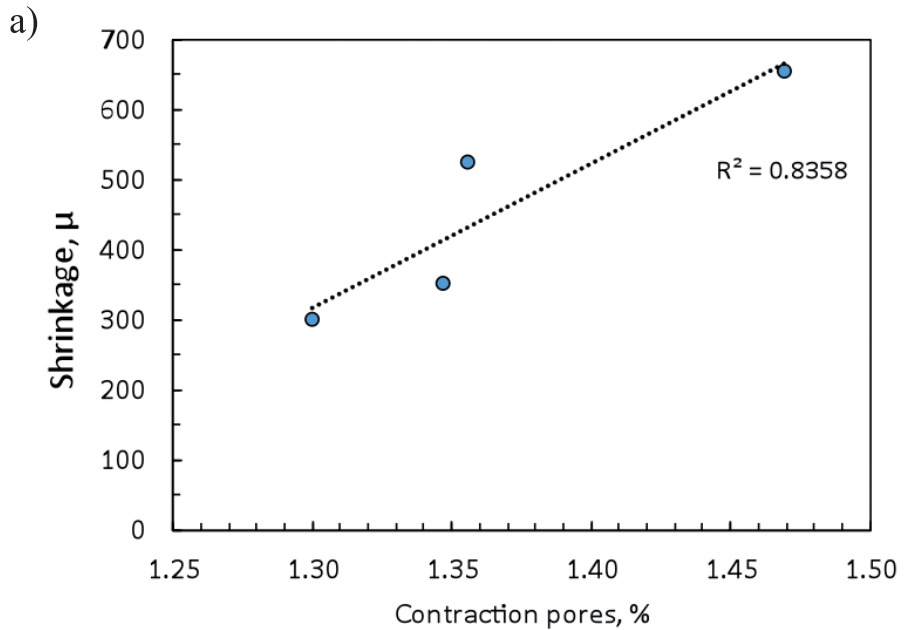

b)

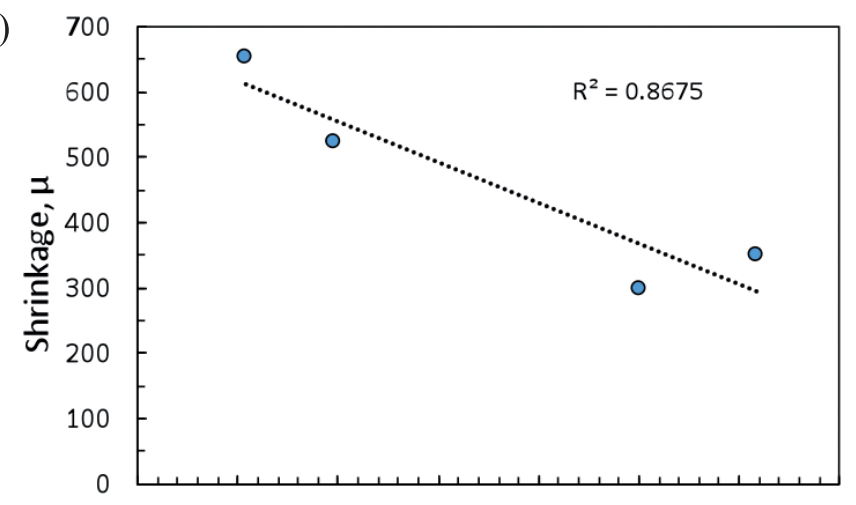

c)

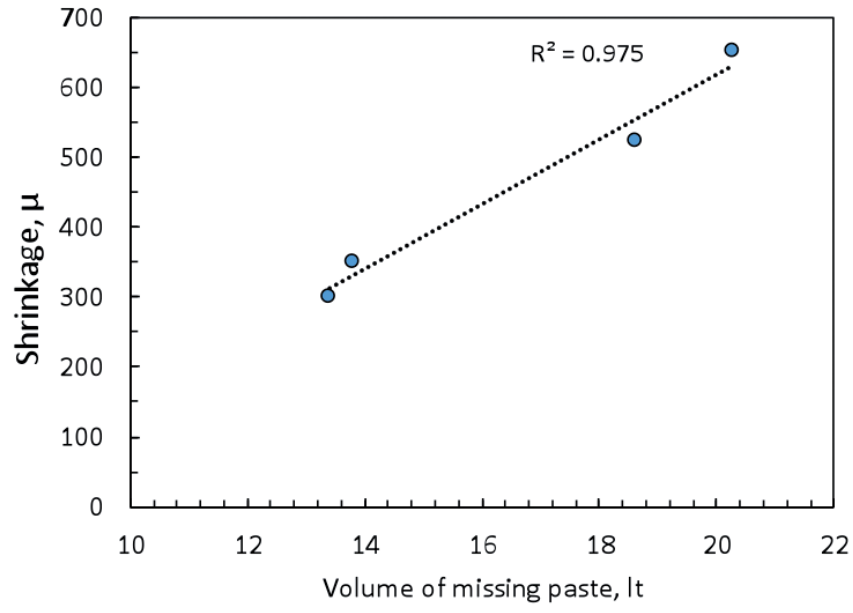

Figure 8: Evolution of estimated microstructural parameters, relation between shrinkage strain and: a) contraction pores, b) volume of capillary water and c) missing paste

to grading of fines in the matrix, which decreases the development of the shrinkage from the increase of amount of paste of mixtures (Bouhamou et al., 2013), can explain this behaviour. The calcium hydroxide occupies the void spaces between the cement grains and, possibly, the high fineness pozzolan, occupy the small spaces between small grains of the fine aggregate (Martirena, 2004). 
surface tension of water). The use of this type of additive gave excellent results in reduction of shrinkage in samples (above $50 \%$ of initial deformations), demonstrating in a collateral way the effectiveness of the Young-Laplace equation as a physical-mathematic tool of explanation of development of capillary tensions due to shrinkage. This mitigation variant (SRAs), is the most effective mitigation solution to deal with the problem.

\section{References}

ACI-209R (1998). Prediction of creep, shrinkage, and temperature effects in concrete structures. American Concrete Institute ACI, Detroit, USA

ACI-231 (2008). Control of shrinkage, early age cracking, causes, measurement and mitigation. American Concrete Institute ACI, Detroit, USA

ASTM C157 (2006). Length change of hardened hydrauliccement mortar and concrete. American Society of Testing and Materials ASTM, USA

Bentz, D.P. and Jensen, O.M. (2004). Mitigation strategies for autogenous shrinkage cracking. Cement and Concrete Composites 26(6), 677-685

Bissonnette, B., Pierre, P. and Pigeon, M. (1999). Influence of key parameters on drying shrinkage of cementitious materials. Cement and Concrete Research 29(10), 1655-1662

Bouhamou, N.E., Belas, N., Bendani, K. and Mebrouki, A. (2013). Shrinkage behavior of a self-compacting concrete. Materiali in tehnologije 47(6), 763-769

Brouwers, H.J.H. (2004). The work of Powers and Brownyard revisited: Part 1. Cement and Concrete Research 34(9), 16971716

Brouwers, H.J.H. (2005). The work of Powers and Brownyard revisited: Part 2. Cement and Concrete Research 35(10), 19221936

Chen, H., Wyrzykowski, M., Scrivener, K. and Lura, P. (2013). Prediction of self-desiccation in low water-to-cement ratio pastes based on pore structure evolution. Cement and Concrete Research 49, 38-47

Eguchi, K. and Teranishi, K. (2005). Prediction equation of drying shrinkage of concrete. Cement and Concrete Research 35(3), 483-493
Fernandez, R. (2008). Calcined clayey soils as a potential replacement for cement in developing countries. $\mathrm{PhD}$ thesis, EPFL, Lausanne, Switzerland

Fujiwara, T. (2008). Effect of aggregate on drying shrinkage of concrete. Journal of Advanced Concrete Technology 6(1), 31-44 Gribniak, V., Kaklauskas, G. and Bacinskas, D. (2008). Shrinkage in reinforced concrete structures: a computational aspect. Journal of Civil Engineering and Management 14(1), 49-60

Güneyisi, E., Gesoĝlu, M. and Mermerdaş, K. (2008). Improving strength, drying shrinkage, and pore structure of concrete using metakaolin. Materials and Structures 41(5), 937-949

Helmuth, R.A. and Turk, D.H. (1967). The reversible and irreversible drying shrinkage of hardened Portland cement and tricalcium silicate pastes. Journal of the Portland Cement Association Research and Development Laboratories 9(2), 8-21

Herrera, L.L. and Ramírez, R. (2014). Evaluation of cracking of concrete in bungalow-like structures caused by retraction induced by relative humidity gradients. Degree project, Universidad Central "Marta Abreu" de Las Villas, Cuba

Howland, J.J. (2012). Performance by durability of reinforced concrete structures. Politechnic Institute of La Havana

Jafarifar, N., Pilakoutas, K. and Bennett, T. (2014). Moisture transport and drying shrinkage properties of steel-fibrereinforced-concrete. Construction and Building Materials 73, $41-50$

Juenger, M.C.G. and Jennings, H.M. (2002). Examining the relationship between the microstructure of calcium silicate hydrate and drying shrinkage of cement pastes. Cement and Concrete Research 32(2), 289-296

Li, J. and Yao, Y. (2001). A study on creep and drying shrinkage of high performance concrete. Cement and Concrete Research 31(8), 1203-1206

Liu, L., Wang, X., Chen, H. and Wan, C. (2016). Microstructurebased modelling of drying shrinkage and microcracking of cement paste at high relative humidity. Construction and Building Materials 126, 410-425

Martirena, J.F. (2004). A compatible environment alternative to reduce the consumption of Portland cement clinker binder. Doctoral thesis, Universidad Central Marta Abreu de Las Villas, Cuba (in Spanish) 
Pan, H., Yang, Z. and Xu, F. (2016). Study on concrete structure's durability considering the interaction of multifactors. Construction and Building Materials 118, 256-261

Rao, A. (2000). Long-term drying shrinkage of mortar-influence of silica fume and size of fine aggregate. Cement and Concrete Research 31(2), 171-175

Sant, G.N. (2009). Fundamental investigations related to the mitigation of volume changes in cement-based materials at early ages. $\mathrm{PhD}$ thesis, Purdue University, USA

Segura, I., Moragues, A. y Anaya, J.J. (2008). Microstructural characterization of cement base materials by destructive tests: part II. Cemento y Hormigón 921, 4-28 (in Spanish)
Sun, W., Chen, H., Luo, X. and Qian, H. (2001). The effect of hybrid fibers and expansive agent on the shrinkage and permeability of high-performance concrete. Cement and Concrete Research 31(4), 595-601

Verbeck, G.J. and Helmuth, R.A. (1969). Structures and physical properties of cement paste. $5^{\text {th }}$ International Congress on the Chemistry of Cement, Tokyo, 1-32

Zhang, J., Hou, D. and Han, Y. (2012). Micromechanical modeling on autogenous and drying shrinkages of concrete. Construction and Building Materials 29, 230-240 